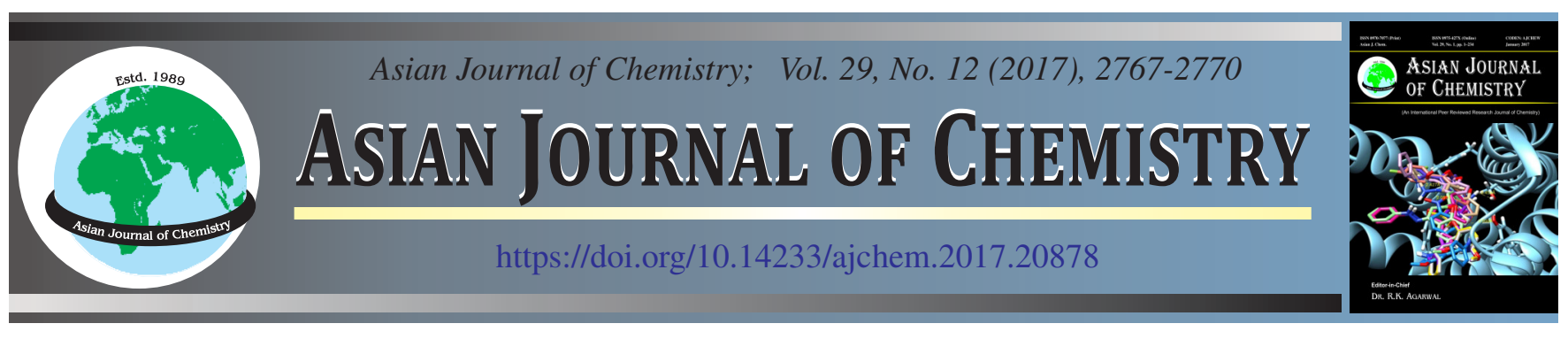

\title{
A New Synthetic Approach to Prostaglandin Analogues: Synthesis of Bimatoprost via Lipase Enzymatic Catalysis
}

\author{
ViJendhar Kamidi ${ }^{1}$, Pooja Kale ${ }^{2}$ and Sathyanarayana Boodida, ${ }^{1, *}$
}

${ }^{1}$ Department of Chemistry, JNTUH College of Engineering Jagtial, Karimnagar-505 501, India

${ }^{2} \mathrm{R} \&$ D Division, Matrica Laboratories Ltd, Nacharam, Hyderabad-500 008, India

*Corresponding author: E-mail: bs14@jntuh.ac.in

\section{INTRODUCTION}

Primary prostaglandins (PGs) have been an attractive target for the chemical synthesis from the early stages of primary prostaglandin research, because of their unique biological properties and relatively simple framework in addition to low natural abundance. Prostaglandins are a family of biologically active compounds that are found in virtually all tissues and organs. The naturally occurring prostaglandins have extremely complex biological functions [1]. They have been targeted for drug development for the treatment of glaucoma. Glaucoma is one of the most common, but serious eye diseases that can lead to optic nerve damage and result in blindness if not appropriately treated [2].

Glaucoma, a heterogeneous family of optic neuropathies, is one of the leading causes of blindness in the developed world. It can characterize by a specific pattern of visual field loss which is the result of the thinning of the ganglion cell layer of the retina and the cupping and excavation of the optic nervehead [3]. Prodrugs of potent, selective prostaglandin FP receptor agonist exhibit similar intraocular pressure (IOP) lowering potencies and efficacies as their endogenous counterpart but elicit greatly reduced ocular side effects, such synthetic prostaglandin analogs like latanoprost (1), travoprost (2) and bimatoprost (4) [4].

Latanoprost (1) and bimatoprost (4) structurally related to PGF $2 \alpha$ are two prostaglandins analogs that continue to hold key positions in the anti-glaucoma drug market, therefore we considered it worthy to reconsider the venerable prostaglandin
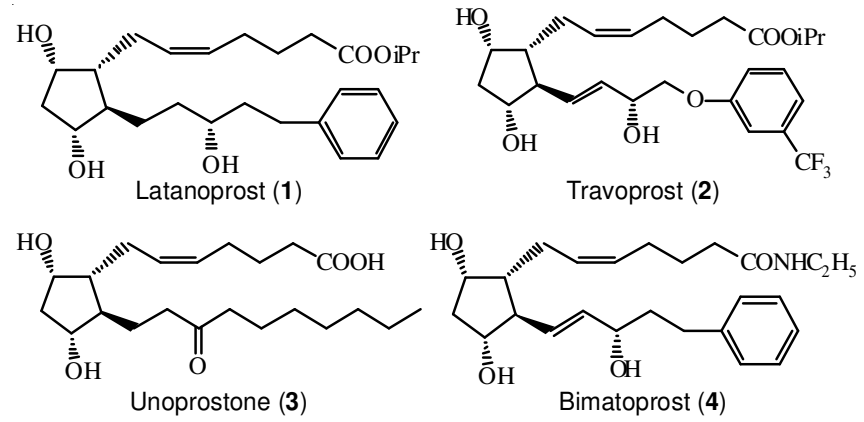

Structures of some prostaglandins

chemistry [5,6]. Bimatoprost (4) is a synthetic prostaglandin used topically for the reduction of elevated intraocular pressure (IOP) in patients with open angle glaucoma or ocular hypertension [7].

$\alpha$-Bromoketones [8,9] and $\alpha$-iodoketones [10] are the most promising intermediates in the organic synthesis due to their high reactivity to react with a variety of nucleophiles to result useful biological active compounds. An alternative method was developed to prepare organophosphorus ylides from $\alpha$-bromoketone and $\alpha$-iodoketone under mild conditions. The successful attack of nucleophilic trivalent phosphorus on a carbon atom was facilitated when the latter is a part of, or conjugated with a carbonyl group [11].

In continuation of our research programme to synthesis of biologically potent prostaglandins [12], we report herein an efficient, cost effective synthetic approach for the synthesis of primary prostaglandins, particulary (15S) bimatoprost (4) 
via lipase enzyme mediated stereo-selective reduction from chiral precursor Corey lactone diol. This method was found to be an efficient with considerable yield, cost effective and minimized the synthetic steps compared to reported procedures. This synthetic route involves Swern oxidation, lipase enzymatic reduction and Wittig reaction conditions as key steps.

\section{EXPERIMENTAL}

All the chemicals, reagents and solvents were purchased from Aldrich (Sigma-Aldrich, USA). The progress of the reaction was examined by thin layer chromatography (TLC), performed on silica gel glass plates containing 60 F-254. The separation of compounds was done by column chromatography using Merck 60-120 mesh silica gel. Infrared spectra were recorded on a Perkin-Elmer RX-1 FT-IR spectrophotometer. ${ }^{1} \mathrm{H}$ NMR spectra were recorded on a Bruker UXNMR/XWI-NMR-400 MHz spectrometer and ${ }^{13} \mathrm{CNMR}(75 \mathrm{MHz})$ spectra were recorded on Bruker Avance-400 MHz spectrometer. All the chemical shifts $(\delta)$ are accounted in parts per million (ppm) with reference to an internal standard TMS. ESI spectra was recorded on Micro mass, Quattro LC using ESI ${ }^{+}$software with a capillary voltage of $3.98 \mathrm{kV}$ and ESI mode positive ion trap detector. Optical rotations of the asymmetric molecules were measured with a Horiba-SEPA-300 digital polarimeter. All the chemical reactions were performed under inert atmosphere.

Synthesis: Compound 11 was prepared as reported previously [12] from triethyl silyl protected (-)-Corey lactone diol by employing well established Swern oxidation and Wittig-Horner synthetic protocols.

Synthesis of 1-bromo-4-phenylbutan-2-one (6): 1-Bromo4-phenylbutan-2-one (6) was prepared by adding bromine $(38.2 \mathrm{~mL}, 1.1 \mathrm{mmol})$ in acetic acid $(1 \mathrm{~mL}, 0.01 \mathrm{vol})$ at $0{ }^{\circ} \mathrm{C}$ to a solution of 4-phenylbutan-2-one (5) $(100 \mathrm{~g}, 1 \mathrm{mmol})$ in methanol $(1000 \mathrm{~mL})$. The mixture was stirred at $15^{\circ} \mathrm{C}$ for $2 \mathrm{~h}$ and reaction mixture was diluted with water $(1000 \mathrm{~mL})$ and extracted with dichloromethane $(2 \times 500 \mathrm{~mL})$ to obtain desired compound $\mathbf{6}$. The organic fraction was collected, washed with brine solution and dried over anhydrous $\mathrm{Na}_{2} \mathrm{SO}_{4}$. The crude compound $\mathbf{6}$ was resulted as a liquid (160 g) after solvent removal under reduced pressure. The spectroscopic data of compound $\mathbf{6}$ matches with the spectral data reported in our previous paper [12].

Synthesis of dimethyl 2-oxo-4-phenylbutylphosphonate (7): Trimethyl phosphate $(87.45 \mathrm{~g}, 1 \mathrm{mmol})$ was added to compound $6(160 \mathrm{~g}, 1 \mathrm{mmol})$ in acetonitrile $(320 \mathrm{~mL})$ at room temperature and stirred for $3 \mathrm{~h}$ at $65^{\circ} \mathrm{C}$. The reaction progress was monitored with TLC. The reaction mixture was dissolved in sodium bicarbonate solution $(1000 \mathrm{~mL})$ and extracted with ethyl acetate $(2 \times 800 \mathrm{~mL})$. The collected organic fractions were washed with sodium chloride solution and dried over sodium sulphate. The solvent was removed under vacuum to afford crude product. The crude compound was chromatographed on silica gel using ethyl acetate and hexane mixture (50:50) to give compound 7 as a liquid (72 g). ${ }^{1} \mathrm{H}$ NMR, ${ }^{13} \mathrm{C}$ NMR spectra of compound 7 matches with the spectral data reported in previous paper [12].

Synthesis of 1-iodo-4-phenylbutan-2-one (8): Iodine (171.49 g, $1 \mathrm{mmol}$ ) was added to a stirred solution of 4-phenylbutan-2-one (5) (100 g, $1 \mathrm{mmol})$ in methanol (300 mL) and MDC (700 mL) mixture. To this solution, copper oxide $(26.87 \mathrm{~g}$,
$0.5 \mathrm{mmol}$ ) was added at room temperature and the reaction mass was heated to reflux at $42{ }^{\circ} \mathrm{C}$ and maintained for $15 \mathrm{~h}$ under reflux. After completion of the reaction, the mass was washed with sodium thiosulphate solution and the collected organic layer was washed with brine, dried over anhydrous $\mathrm{Na}_{2} \mathrm{SO}_{4}$ and the solvent was evaporated under reduced pressure to afford crude compound $\mathbf{8}$ as a liquid ( $200 \mathrm{~g}$ ). The crude compound was dissolved in ethanol $(600 \mathrm{~mL})$, cooled in refrigerator for $5 \mathrm{~h}$ and filtered to obtain pure compound as solid (130 g). ${ }^{1} \mathrm{H}$ NMR $(400 \mathrm{MHz}$, $\left.\mathrm{CDCl}_{3}\right): \delta 2.9(\mathrm{~m}, 2 \mathrm{H}), 3.1(\mathrm{~m}, 2 \mathrm{H}), 3.8(\mathrm{~s}, 2 \mathrm{H}), 7.2(\mathrm{~m}, 3 \mathrm{H}), 7.3$ $(\mathrm{m}, 2 \mathrm{H})$.

(3aR,4R,5R,6aS)-Hexahydro-5-hydroxy-4-((S,E)-3triethylsilyloxy-5-phenylpent-1-enyl)cyclopenta[b]furan-2one (12): Compound 11 (30 g) was added to $0.1 \mathrm{M}$ phosphate buffer solution and maintained $\mathrm{pH}$ around 7-7.5 and stirred solution for $20 \mathrm{~min}$. CAL-B enzyme ( $3 \mathrm{~g}$ ) was added slowly at $27^{\circ} \mathrm{C}$ and stirred reaction mixture for $5 \mathrm{~h}$ at the same temperature. After reaction completion, the reaction mixture was treated with sodium bicarbonate solution and extracted with $n$-hexane $(2 \times 300 \mathrm{~mL})$, dried over $\mathrm{Na}_{2} \mathrm{SO}_{4}$. The solvent was removed under vacuum to afford pure compound $\mathbf{1 2}$ as a liquid $(20 \mathrm{~g})$. ${ }^{1} \mathrm{H}$ NMR $\left(400 \mathrm{MHz}, \mathrm{CDCl}_{3}\right): \delta 0.5(\mathrm{~J} / \mathrm{Hz}=7.86, \mathrm{q}, 6 \mathrm{H}), 0.9(\mathrm{~J} /$ $\mathrm{Hz}=8.0, \mathrm{t}, 9 \mathrm{H}), 1.8(\mathrm{~m}, 2 \mathrm{H}), 2.0(\mathrm{~m}, 1 \mathrm{H}), 2.3(\mathrm{~m}, 1 \mathrm{H}), 2.4(\mathrm{~m}$, $2 \mathrm{H}), 2.7(\mathrm{~m}, 4 \mathrm{H}), 3.9(\mathrm{~J} / \mathrm{Hz}=6.03, \mathrm{q}, 1 \mathrm{H}), 4.1(\mathrm{~J} / \mathrm{Hz}=6.26, \mathrm{q}$, $1 \mathrm{H}), 4.9(\mathrm{~m}, 1 \mathrm{H}), 5.5(\mathrm{~m}, 1 \mathrm{H}), 5.6(\mathrm{~m}, 1 \mathrm{H}), 7.2(\mathrm{~J} / \mathrm{Hz}=12.6$, t, $3 \mathrm{H}), 7.3(\mathrm{~J} / \mathrm{Hz}=12.9, \mathrm{~d}, 2 \mathrm{H})$.

(3aR,4R,5R,6aS)-Hexahydro-4-((S,E)-3-triehylsilyloxy5-phenylpent-1-enyl)-2H-cyclopenta[b]furan-2,5-diol (13): To a solution of compound $\mathbf{1 2}(31 \mathrm{~g}, 1 \mathrm{mmol})$ in THF $(310 \mathrm{~mL})$, DIBAL-H (260 mL, $3.5 \mathrm{mmol})$ was added dropwise at $70^{\circ} \mathrm{C}$ and continued stirring for 30-45 min. The reaction progress was monitored by TLC, the reaction was quenched with methanol $(77.5 \mathrm{~mL})$ below $70{ }^{\circ} \mathrm{C}$, then reaction temperature was raised to $5{ }^{\circ} \mathrm{C}$, water $(77.5 \mathrm{~mL})$, ethyl acetate $(77.5 \mathrm{~mL})$ were added to reaction mixture and continued stirring for 30 min at room temperature (solid formed). The reaction mixture was filtered through a celite pad and washed with ethyl acetate $(310 \mathrm{~mL})$. The organic layer was treated with sodium chloride solution, dried over anhydrous $\mathrm{Na}_{2} \mathrm{SO}_{4}$ and concentrated under reduced pressure to give compound $\mathbf{1 3}$ as a colourless liquid (31 g, 99.6\%).

(5Z)-Methyl-7-((1R,2R,3R,5S)-3,5-dihydroxy-2-((S,E)3-hydroxy-5-phenylpent-1-enyl)cyclopentyl)hept-5-enoate (14): To a solution of 4-carboxy butyltriphenyl phosphonium bromide (114.87 g, $3.5 \mathrm{mmol}$ ), potassium $t$-butoxide (49.83 $\mathrm{g}, 6 \mathrm{mmol})$ in THF (248 $\mathrm{mL})$, compound 13 was added $(31 \mathrm{~g}$, $1 \mathrm{mmol})$ in THF $(64 \mathrm{~mL})$ at $5{ }^{\circ} \mathrm{C}$ and the reaction mixture was stirred for $4 \mathrm{~h}$. After reaction completion, reaction contents were poured into the cold water $(155 \mathrm{~mL})$ and solution $\mathrm{pH}$ was adjusted to 2 with $\mathrm{NaHSO}_{4}$ solution, continued stirring for another $1 \mathrm{~h}$. Aqueous layer was extracted with ethyl acetate $(2 \times 155 \mathrm{~mL})$, organic fractions were washed with brine solution, dried over anhydrous $\mathrm{Na}_{2} \mathrm{SO}_{4}$ and removed solvent under reduced pressure. The obtained crude acid derivative (40 g) was used for the next step without further purification.

To a solution of crude acid compound $(147 \mathrm{~g})$ in acetone (620 mL), methyl iodide (105 g, $10 \mathrm{mmol}$ ) and potassium carbonate $(153.48 \mathrm{~g}, 15 \mathrm{mmol})$ was added at room temperature 
and stirred reaction mixture for $16 \mathrm{~h}$. After reaction completion, the reaction mixture was filtered and washed with acetone. The organic solvent was removed completely under vacuum below $40{ }^{\circ} \mathrm{C}$ and obtained residue was dissolved in dichloromethane $(310 \mathrm{~mL})$, washed with citric acid solution $(155 \mathrm{~mL})$, $\mathrm{Na}_{2} \mathrm{CO}_{3}$ solution $(155 \mathrm{~mL})$ and dried over anhydrous $\mathrm{Na}_{2} \mathrm{SO}_{4}$. The solvent removed under reduced pressure to obtain crude ester compound 14 (150 g). The resulted compound 14 was purified by column chromatography on silica gel using with dichloromethane and acetone (70:30) mixture to afford compound 14 as a colorless liquid (17 g). ${ }^{1} \mathrm{H}$ NMR (400 MHz, $\left.\mathrm{CDCl}_{3}\right): \delta$ $1.5(\mathrm{~m}, 1 \mathrm{H}), 1.65(\mathrm{~m}, 3 \mathrm{H}), 1.8(\mathrm{q}, 4 \mathrm{H}), 2.2(\mathrm{~m}, 9 \mathrm{H}), 2.65(\mathrm{~m}, 2 \mathrm{H})$, $3.6(\mathrm{~s}, 3 \mathrm{H}), 3.95(\mathrm{~m}, 1 \mathrm{H}), 4.1(\mathrm{q}, 1 \mathrm{H}), 4.2(\mathrm{~m}, 1 \mathrm{H}), 5.5(\mathrm{~m}, 4 \mathrm{H})$ $7.2(\mathrm{~m}, 3 \mathrm{H}), 7.3(\mathrm{~m}, 2 \mathrm{H})$.

(5Z)-N-Ethyl-7-((1R,2R,3R,5S)-3,5-dihydroxy-2-((S,E)3-hydroxy-5-phenylpent-1-enyl)cyclopentyl)hept-5-enamide (4): Compound 14 (17 g) was charged with ethylamine solution $(185 \mathrm{~mL}, 5 \mathrm{vol})$ and stirred solution for $36 \mathrm{~h}$ at room temperature. After completion of reaction, solvent was removed under vacuum, treated with ethyl acetate and water and allowed to stand for separation of aqueous and organic layers. The organic layer was dried over $\mathrm{Na}_{2} \mathrm{SO}_{4}$ and concentration of solvent results solid compound which stirred in methyl tertiary butyl ether. The desired solid compound further purified in ethyl acetate. ${ }^{1} \mathrm{H}$ NMR $\left(300 \mathrm{MHz}, \mathrm{CDCl}_{3}\right): \delta 1(\mathrm{~J} / \mathrm{Hz}=7.1, \mathrm{t}, 3 \mathrm{H})$, $1.3(\mathrm{~m}, 4 \mathrm{H}), 1.6(\mathrm{~m}, 2 \mathrm{H}), 2.0(\mathrm{~m}, 8 \mathrm{H}), 2.5(\mathrm{~m}, 2 \mathrm{H}), 3.0(\mathrm{~m}, 2 \mathrm{H})$, $3.6(\mathrm{~m}, 1 \mathrm{H}), 3.9(\mathrm{~m}, 2 \mathrm{H}), 4.3(\mathrm{~J} / \mathrm{Hz}=4.8, \mathrm{~d}, 1 \mathrm{H}), 4.5(\mathrm{~J} / \mathrm{Hz}=5.7$, $\mathrm{d}, 1 \mathrm{H}), 4.6(\mathrm{~J} / \mathrm{Hz}=4.8 \mathrm{~Hz}, \mathrm{~d}, 1 \mathrm{H}), 5.3(\mathrm{~m}, 4 \mathrm{H}), 7.2(\mathrm{~m}, 5 \mathrm{H})$, $7.6(\mathrm{~s}, 1 \mathrm{H}) .{ }^{13} \mathrm{C} \mathrm{NMR}\left(300 \mathrm{MHz}, \mathrm{CDCl}_{3}\right): \delta 14.89,25.49,25.69$, 26.76, 31.97, 34.46, 35.92, 38.84, 43.01, 50.49, 55.69, 72.27, $72.59,77.95,125.86,128.44,128.54,129.22,129.82,133.13$, 135.08, 142.1, 173.32. IR (Neat, $\left.\mathrm{cm}^{-1}\right): \lambda_{\max } 1626.66,2925.48$, 3336.25, 3418.21. MS (ESI) m/z: 415.43 (M+1); HRMS (ESI): $m / z$ calcd for $\mathrm{C}_{25} \mathrm{H}_{37} \mathrm{NO}_{4}$. [M] 415.43. SOR: 34.3.

\section{RESULTS AND DISCUSSION}

An improved methodology was developed for the preparation of organophosphorus reagent 7 from $\alpha$-bromoketone (6) and $\alpha$-iodoketone (8) (Schemes I and II). First, 4-phenylbutan-2one (5) was transformed into 1-bromo-4-phenylbutan-2-one (6) by treating with bromine in acetic acid. Subsequently, compound 6 were directly converted to corresponding organophosphorus ylide without transforming it into iodo derivate as reported in our previous paper [12]. Further, we have developed an alternative synthetic route for the synthesis of compound 7, from an iodo derivative of 4-phenylbutan-2-one (5) with an improved yield. In the alternative route, 4-phenylbutan-2-one (5) was treated with cupric oxide/iodine in methanol and methylene chloride mixture at $42^{\circ} \mathrm{C}$ for $15 \mathrm{~h}$ to obtain an iodo-intermediate (8). This intermediate was further treated with trimethyl phosphite to obtain compound $\mathbf{7}$ in good yield.

We have previously reported the synthesis of compound 11 from (-)-Corey lactone diol (9) using Swern oxidation and Wittig-Horner reaction conditions as key steps as reported earlier [12]. Compound $\mathbf{1 1}$ was prepared by employing Swern oxidation and Wittig-Horner reaction conditions on triethyl silyl chloride protected Corey lactone diol. Selective functional group transformation of compound $\mathbf{1 1}$ was carried out using lipase enzyme. The ketone functional group was converted selectively to hydroxy functional group leaving double bond by employing stereoselective enzymatic reduction conditions at $0^{\circ} \mathrm{C}$ for $3 \mathrm{~h}$ to obtain hydroxy compound $\mathbf{1 2}$.

Subsequently, lactone ring of compound $\mathbf{1 2}$ was reduced to the corresponding lactol in the presence of DIBAL-H in $\mathrm{THF}$ at $70^{\circ} \mathrm{C}$ for $1 \mathrm{~h}$ to give compound 13 . However, the ring opening of lactol was accomplished by treating with suitable organophosphonium reagent; 4-carboxybutyl triphenyl phosphonium bromide in basic medium under mild Wittig reaction conditions. The resulting Wittig product without further purification was converted to ester by treating with $\mathrm{K}_{2} \mathrm{CO}_{3}$ and methyl iodide in acetone at $30^{\circ} \mathrm{C}$ for $16 \mathrm{~h}$ to get compound 14. Finally, compound 14 was treated with ethyl amine at $25^{\circ} \mathrm{C}$ for $40 \mathrm{~h}$ to afford crude amide compound $\mathbf{4}$ in quantitative yield and crude compound was recrystallized in dissolving ethyl acetate to get target compound bimatoprost (4). Hence, we have demonstrated that the present methodology facilitates an effective stereo selective enzymatic reduction of ketone functional group with an improved yield for the synthesis of compound $\mathbf{4}$ as shown in Scheme-III.

\section{Conclusion}

We have demonstrated a simple, convenient and convergent synthetic approach for the synthesis of (15S) bimatoprost using a lipase enzyme. This enzyme mediated stereo selective reduction was found to be an efficient, cost effective and decreased number of synthetic steps with an improved yield from chiral

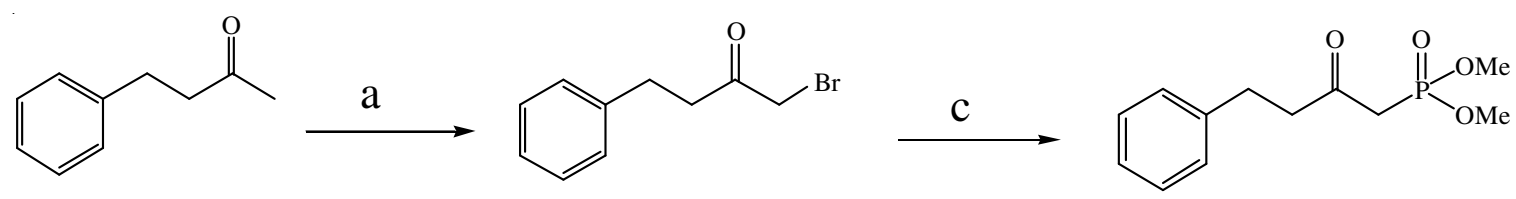

6

7

Scheme-I: Reagents and conditions: (a) $\mathrm{Br}$, acetic acid, methanol, $0{ }^{\circ} \mathrm{C}, 4 \mathrm{~h}$; (c) $\left(\mathrm{CH}_{3}\right)_{3} \mathrm{PO}_{3}$, acetonitrile, $65^{\circ} \mathrm{C}, 3 \mathrm{~h}$<smiles>CC(=O)CCc1ccccc1</smiles>
5<smiles>O=C(CI)CCc1ccccc1</smiles>

8<smiles>COP(=O)(CC(=O)CCc1ccccc1)OC</smiles>

7

Scheme-II: Reagents and conditions: (b) $\mathrm{CuO}$, iodine, $\mathrm{MeOH}, \mathrm{MDC}, 42{ }^{\circ} \mathrm{C}, 15 \mathrm{~h}$; (c) $\left(\mathrm{CH}_{3}\right)_{3} \mathrm{PO}_{3}$, acetonitrile, $65{ }^{\circ} \mathrm{C}, 3 \mathrm{~h}$ 
<smiles>O=C1C[C@H]2[C@@H](CO)C[C@@H](O)[C@@H]2C1</smiles>

9

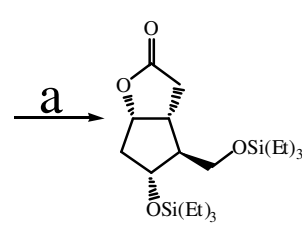

10
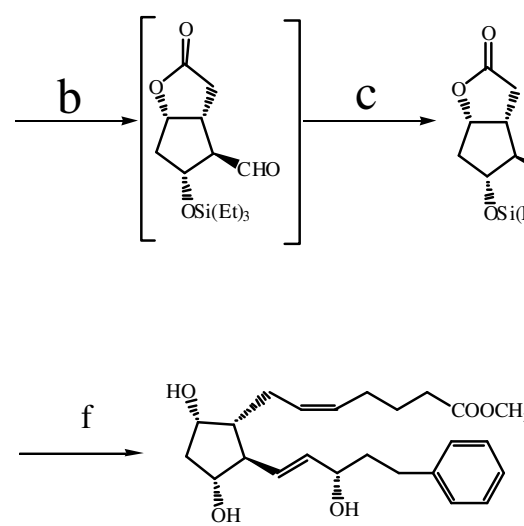

14

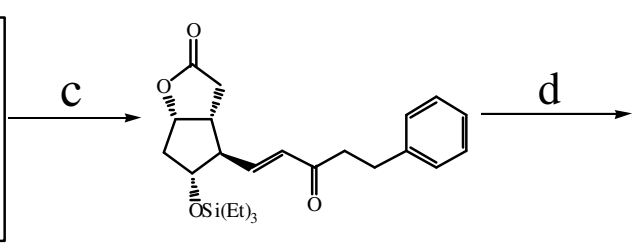

11

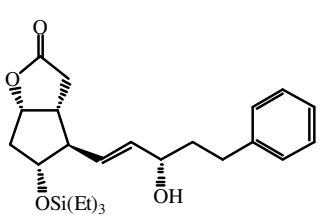

12

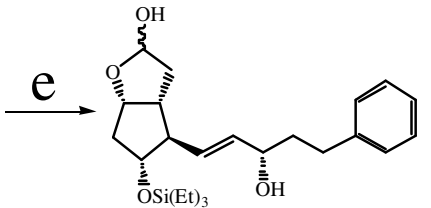

13

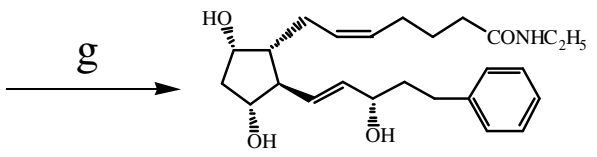

Bimatoprost (4)

Scheme-III: Reagents and conditions: (a) Triethyl silylchloride, imidazole, DMF $5{ }^{\circ} \mathrm{C}, 4 \mathrm{~h}$; (b) $(\mathrm{COCl})_{2}, \mathrm{DMSO}_{2} \mathrm{Et}_{3} \mathrm{~N}, \mathrm{CH}_{2} \mathrm{Cl}_{2},-72{ }^{\circ} \mathrm{C}, 4$ h; (c) Compound 7, methyl tertiary butyl ether, $\mathrm{LiOH} \cdot \mathrm{H}_{2} \mathrm{O}, 5^{\circ} \mathrm{C}, 45 \mathrm{~min}$; (d) enzyme, $0{ }^{\circ} \mathrm{C}, 3 \mathrm{~h}$; (e) DIBAL-H, dry $\mathrm{THF},-70{ }^{\circ} \mathrm{C}$, $60 \mathrm{~min}$; (f) 4-Carboxy butyl triphenyl phosphonium bromide, $t$-BuOK, THF, $5{ }^{\circ} \mathrm{C}, 6 \mathrm{~h}$; methyl iodide, potassium carbonate, acetone, $30^{\circ} \mathrm{C}, 16 \mathrm{~h} ;(\mathrm{g})$ ethyl amine, $25^{\circ} \mathrm{C}, 40 \mathrm{~h}$

precursor Corey lactone diol. This new synthetic approach involves the Swern oxidation, stereo-selective enzymatic reduction and Wittig reaction conditions as key steps for the synthesis of compound $\mathbf{4}$ in good yield.

\section{ACKNOWLEDGEMENTS}

One of the authors, $\mathrm{KV}$ is grateful to Matrica Laboratories Ltd., for providing research opportunity to carry out this research work.

\section{REFERENCES}

1. D. De Souza, M. Albert and H. Sturn, Improved Process for the Production of Bimatoprost, US Patent US2011/0178340 A1 (2011).

2. H. Mudduluru, R. M. Hindupur, P. K. Dubey, S. Madhavaram, L. Tatini and G. V. Subbaraju, Lett. Org. Chem., 8, 234 (2011); https://doi.org/10.2174/157017811795371485.

3. M.R. Hellberg, R.E. Conrow, N.A. Sharif, M.A. McLaughlin, J.E. Bishop, J.Y. Crider, W.D. Dean, K.A. De Wolf, D.R. Pierce, V.L. Sallee, R.D. Selliah, B.S. Severns, S.J. Sproull, G.W. Williams, P.W. Zinke and P.G. Klimko, Bioorg. Med. Chem., 10, 2031 (2002);

https://doi.org/10.1016/S0968-0896(02)00016-0.
4. P. Klimko, M. Hellberg, M. McLaughlin, N. Sharif, B. Severns, G. Williams, K. Haggard and J. Liao, Bioorg. Med. Chem., 12, 3451 (2004); https://doi.org/10.1016/j.bmc.2004.04.034.

5. G. Zanoni, A. D'Alfonso, A. Porta, L. Feliciani, S.P. Nolan and G. Vidari, Tetrahedron, 66, 7472 (2010); https://doi.org/10.1016/j.tet.2010.07.069.

6. Z. Feng, M.R. Hellberg, N.A. Sharif, M.A. McLaughlin, G.W. Williams, D. Scott and T. Wallace, Bioorg. Med. Chem., 17, 576 (2009); https://doi.org/10.1016/j.bmc.2008.11.070.

7. Allergan gets FDA approval, Business Week, Associated Press (2008).

8. A.K. Macharla, R. Chozhiyath Nappunni, M.R. Marri, S. Peraka and N. Nama, Tetrahedron Lett., 53, 191 (2012); https://doi.org/10.1016/j.tetlet.2011.11.011.

9. K.M. Maloney and J.Y.L. Chung, J. Org. Chem., 74, 7574 (2009); https://doi.org/10.1021/jo901552k.

10. M.R. Marri, A.K. Macharla, S. Peraka and N. Nama, Tetrahedron Lett., 52, 6554 (2011); https://doi.org/10.1016/j.tetlet.2011.09.106.

11. M.T. Maghsoodlou, S.M.H. Khorassani, M.K. Rofouei, S.R. Adhamdoust and M. Nassiri, ARKIVOC, 145 (2006);

https://doi.org/10.3998/ark.5550190.0007.c17.

12. K. Vijendhar, B. Srinivas and S. Boodida, J. Chem. Sci., 127, 2023 (2015); https://doi.org/10.1007/s12039-015-0963-2. 